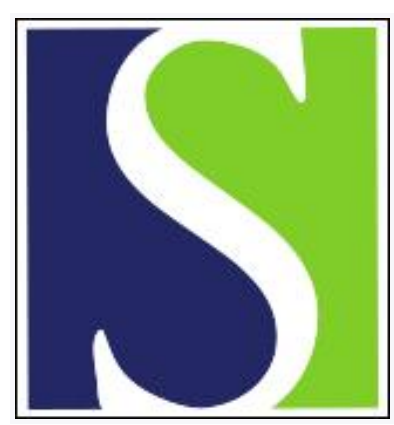

Scand J Work Environ Health 1999;25(2):137-143

https://doi.org/10.5271/sjweh.416

Issue date: Apr 1999

Nasal patency and lavage biomarkers in relation to settled dust and cleaning routines in schools

by Wålinder R, Norbäck D, Wieslander G, Smedje G, Erwall C, Venge P

The following article refers to this text: 2006;32(5):374-382

Key terms: acoustic rhinometry; albumin; cleaning; dust; eosinophil cationic protein; indoor air pollution; lysozyme; myeloperoxidase; nasal obstruction; school environment

This article in PubMed: www.ncbi.nlm.nih.gov/pubmed/10360469

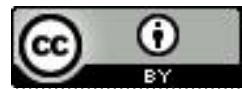




\title{
Nasal patency and lavage biomarkers in relation to settled dust and cleaning routines in schools
}

\author{
by Robert Wålinder, MD, ${ }^{1}$ Dan Norbäck, PhD, ${ }^{1}$ Gunilla Wieslander, MD, ${ }^{1}$ Greta Smedje, ${ }^{1}$ Claes Erwall, \\ $M D,{ }^{2}$ Per Venge, $M D^{3}$
}

Wålinder R, Norbäck D, Wieslander G, Smedje G, Erwall C, Venge P. Nasal patency and lavage biomarkers in
relation to settled dust and cleaning routines in schools. Scand J Work Environ Health 1999;25(2):137-143.

Objectives This study determined the relations between settled dust and cleaning routines in classrooms on one hand, and nasal symptoms, nasal cavity dimensions, and the concentration of selected biomarkers of inflammation in nasal lavage on the other.

Methods Measurements of settled dust via standardized vacuum cleaning and an investigation of the cleaning routines were performed in 12 randomly selected primary schools in the municipality of Uppsala. Clinical examinations including acoustic rhinometry and nasal lavage were performed in the school environment among 279 school personnel working in the main buildings of the schools. Eosinophil cationic protein (ECP), myeloperoxidase (MPO), lysozyme, and albumin were analyzed in the lavage fluid. The relationships between the medical and hygienic data were analyzed both bivariately and with a multiple regression model controlling for age, gender, smoking, atopy, room temperature, and urban vicinity of the school.

Results The amount of settled dust was positively related to subjective nasal obstruction and smaller nasal cavity dimensions measured with acoustic rhinometry. The noses were less patent, and the levels of ECP or lysozyme in the lavage were increased for the subjects in schools with a lower frequency of floor mopping, a lower frequency of desk cleaning, and where wet mopping was used.

Conclusions Our results indicate that the actual dust levels in Swedish classrooms can affect the occurrence of nasal obstruction among school personnel. A beneficial effect on the clinical signs of the nasal mucosa was observed for a higher frequency of both floor mopping and desk cleaning, whereas the use of wet mopping seemed disadvantageous in comparison with dry mopping. These findings illustrate the need for adequate cleaning procedures to minimize the environmental effects on the airway mucosa.

Key terms acoustic rhinometry, albumin, cleaning, dust, eosinophil cationic protein, indoor air pollution, lysozyme, myeloperoxidase, nasal obstruction, school environment.

In a thesis on the school environment in Stockholm in 1879, Elias Heyman stressed the importance of cleaning. He pointed out that a sufficient air exchange rate is an important issue, but improved ventilation cannot solve the problem with settled dust contaminants (1). Settled dust contaminants and poor cleaning in schools have again become an issue during the last decade. It has been demonstrated that, in Scandinavian schools, there is widespread contamination by cat and dog allergens $(2$, 3 ) and sometimes mite allergens $(4,3)$ due to a combination of accumulation of dust and poor cleaning. Settled dust may also contain various other types of pollut- ants, including microbial contaminants (5), pesticides, metals, and polycyclic aromatic hydrocarbons (PAH) (6).

Earlier studies from offices have shown that the sick building syndrome is related to cleaning routines (7) and contaminants in settled dusts $(8,9)$. In the large Danish Town Hall study from the 1980 s, settled macromolecular organic dust was shown to be one important exposure indicator related to the sick building syndrome in office workers (8). Later, Gyntelberg and his co-workers demonstrated a relationship between sick building syndrome and the content of endotoxin, fibers, and volatile organic compounds in settled dust from offices. They

1 Department of Medical Sciences, Occupational and Environmental Medicine, Uppsala University Hospital, Sweden.

2 Department of Oto-Rhino-Laryngology and Head and Neck Surgery, Uppsala University Hospital, Sweden.

3 Department of Medical Sciences, Clinical Chemistry and Asthma Research Centre, Uppsala University Hospital, Sweden.

Reprint requests to: Dr Robert Wålinder, Department of Clinical Physiology, Uppsala University Hospital, SE-751 85 Uppsala, Sweden. [E-mail: robert.walinder@occmed.uu.se] 
also demonstrated a relationship between the histamine release of the dust, in an in vitro test, and the prevalence of sick building syndrome among office workers (9).

In our previous school studies, we have demonstrated a relationship between settled dust and the perception of air quality (10). To our knowledge, little information is available on the relation between clinical signs on one hand, and cleaning routines or settled dust contamination in schools on the other.

Recently, objective methods for studying environmental effects on the upper airways have been developed. One objective method that can be applied in epidemiologic field studies of nasal congestion is acoustic rhinometry (11). Measurable effects on the degree of nasal mucosal swelling have been demonstrated for exposures to dust and volatile organic compounds (12). Nasal lavage is also a well documented technique for studying inflammatory effects in the nasal mucosa in relation to inhalatory exposure $(13,14)$. Experimental studies with nasal lavage have shown that there is a large number of possible biomarkers, including tryptase, albumin, lysozyme,

Table 1. Arithmetic means and medians with deviations for the measurements of the total amount and the contents of settled dust in the classrooms of the 12 schools.

\begin{tabular}{lrrrr}
\hline Amount per sample & $\begin{array}{c}\text { Arithmetic } \\
\text { mean }\end{array}$ & SD & Median & $\begin{array}{c}\text { Interquartile } \\
\text { range }\end{array}$ \\
\hline Total dust (mg) & 109 & 519 & 108 & $82-160$ \\
Cat allegen (Der f1) (ng) & 12 & 11 & 11 & $2.2-20$ \\
Dog allergen (Can d1)(ng) & 51 & 76 & 22 & $17-49$ \\
Mite allergen (ng) & 0.25 & 0.88 & 0 & $0-3.0$ \\
Endotoxin (ng) & 0.28 & 0.15 & 0.32 & $0.17-0.34$ \\
\hline
\end{tabular}

Table 2. Absolute frequencies of schools and relative frequencies of subjects according to the floor and desk cleaning routines used.

\begin{tabular}{lcc}
\hline Frequency or type of cleaning & $\begin{array}{c}\text { Number } \\
\text { of schools } \\
(\mathrm{N}=12)\end{array}$ & $\begin{array}{c}\text { Proportion } \\
\text { of subjects } \\
(\mathrm{N}=234)\end{array}$ \\
\hline Type of floor cleaning & & \\
Wet or wet and dry mopping & 9 & 68 \\
Only dry mopping & 3 & 32 \\
Frequency of floor cleaning & & \\
Never & - & - \\
Once/week & - & - \\
Twice/week & 3 & 43 \\
Three times/week & - & - \\
Four times/week & 2 & 10 \\
Five times/week & 7 & 47 \\
Frequency of desk cleaning & & \\
Never & 2 & 35 \\
Once/week & 6 & 35 \\
Twice/week & 1 & 14 \\
Three times/week & 2 & 9 \\
Four times/week & - & - \\
Five times/week & 1 & 6 \\
\hline
\end{tabular}

a In all schools the floor cleaning of the examined classrooms was performed by manual mopping, either wet, dry or both. eosinophil cationic protein (ECP) emitted from the granula of activated eosinophil granulocytes, and myeloperoxidase (MPO) emitted from activated neutrophil granulocytes $(15,16)$.

The aim of our investigation was to study possible relationships between signs of inflammation and swelling of the nasal mucosa among school personnel on one hand and settled dust and cleaning routines in schools on the other.

\section{Subjects and methods}

\section{Measurement of settled dust, allergens and endotoxin}

During March-May 1993, settled dust was collected in classrooms by means of standardized vacuum cleaning. In each school, two classrooms were randomly selected within the buildings, irrespective of the degree of complaints of the pupils or teachers in the different classrooms. Settled dust was collected as a mixed sample via standardized vacuum cleaning for 4 minutes, equally distributed between desks, chairs and the floor $(400 \mathrm{~W}$ vacuum cleaner provided with a special dust collector from ALK Laboratories, Copenhagen, containing a Millipore filter, pore size $6 \mu \mathrm{m}$ ). Two equal dust samples were collected from each classroom, one from each half of the room. After passing through a sieve containing a filter with a porosity of $300 \mu \mathrm{m}$, the amount of fine dust from the first filter was determined by weighing the filters. Cat (Fel d 1) and $\operatorname{dog}$ (Can $\mathrm{f} 1$ ) allergens were quantified with an enzyme-linked immunosorbent assay using monoclonal antibodies (2). Major mite allergens in the dust were determined by enzyme immunoassays (4). The 2 nd dust sample was analyzed without sieving and was analyzed for guanine by the semiquantitative acarex test (17) and for endotoxin by means of the limulus amebocyte lysate test (18). The amount of allergens or endotoxin in each sample was calculated by multiplying the amount of dust by the concentration of the particular contaminant in the collected dust, and it was expressed as nanograms per sample.

Cat and dog allergens were detected in all the schools except one. One of the schools had a positive antibody test to house dust mites, and the acarex test showed the presence of traces of guanine in 2 other schools. The amounts of settled dust and specific contaminants measured are given in table 1.

\section{Assessment of cleaning routines}

Information on cleaning routines was gathered by an occupational hygienist visiting the schools twice, at the beginning and at the end of the study period. Concerning floor cleaning, only manual mopping was used in the classrooms, either wet, dry, or both. The number of 
schools and the proportion of subjects working are given in table 2 for the frequencies of cleaning and the type of cleaning.

\section{Subjects}

The source population comprised all primary school personnel in the municipality of Uppsala. In 1993, all 62 primary schools in the municipality of Uppsala were identified, and, out of these, 18 were randomly selected for a larger longitudinal study applying both self-administered questionnaires and hygienic indoor measurements in 1993 (10) and 1995. A restriction of the present study was to include the 12 schools that only comprised the first 6 classes (pupils age 7-12 years) and that had had no changes in the ventilation system or no redecoration during the study period (from March 1993 to March 1995, off pollen season). Another restriction of the study was to include only the subjects working in the main buildings of the schools where the hygienic measurements were made. Identification of the subjects was made via current lists of employees, and subjects on sick leave or off duty for other reasons at the time of investigation, or normally working less than 20 hours per week, were excluded. Subjects who had an infection or fever during the week prior to the examination were asked to come to a follow-up investigation 2 to 4 weeks later.

Out of 279 persons working at least 20 hours per week in the main buildings of the 12 schools, 42 did not want to participate. Three subjects were excluded from the investigation, 2 because of a febrile reaction both at the time of investigation and at the follow-up session, and the 3rd because of pregnancy. Altogether 234 participated in the study (84\%). Information on symptoms, nasal lavage, and acoustic rhinometry was obtained from 234,234 , and 229 subjects, respectively.

\section{Personal factors and symptoms}

The subjects were questioned by a physician about allergy or other diseases, medication, occupational data, smoking habits, and social status. An operational definition for the assessment of atopy was a history of allergic manifestations related to exposure to common Swedish allergens mediated through immunoglobulin E (Ig E) (tree pollen, grass pollen, or furry animals) reported in the medical interview. The percentage of current smokers was $15 \%$, the median age was 46 years $(22-62$ years), and $70 \%$ were women. For $23 \%$ there was a history of atopy, and $8 \%$ had a history of asthma.

A questionnaire was administered, including 4 questions on nasal symptoms, the week prior to the examination; they concerned nasal obstruction, discharge, itch, and sneezing.

\section{Acoustic rhinometry}

Acoustic rhinometry (Rhin 2000, SR Electronics, Denmark; wideband noise; continuously transmitted) was performed in the school building, and each person had been at the workplace at least 1 hour prior to the examination. The measurements were made under standardized conditions (sitting), after 5 minutes of rest. By means of acoustic reflection the minimal cross-sectional areas (MCA) on each side of the nose were measured 0 to $22 \mathrm{~mm}$ (MCA1) and 23 to $54 \mathrm{~mm}$ (MCA2) from the nasal opening. The volumes of the nasal cavity on the right and left side were also measured from 0 to $22 \mathrm{~mm}$ (VOL1) and from 23 to $54 \mathrm{~mm}$ (VOL2). The mean values were calculated from 3 subsequent measurements on each side of the nose. Data on nasal dimensions are presented as the sum of the values from the right and the left sides.

\section{Nasal lavage}

Lavage of the nasal mucosa was made with a $20-\mathrm{ml}$ plastic syringe attached to a nose olive after the rhinometric measurement. The subjects were standing, with their head flexed about 30 degrees forward. Room-temperature $\left(20-22^{\circ} \mathrm{C}\right)$, sterile $0.9 \%$ saline solution was introduced into the nasal cavity. Each nostril was lavaged with a 5$\mathrm{ml}$ solution that was flushed back and forth 5 times via the syringe, at an interval of a few seconds. The fluid was transferred into $10-\mathrm{ml}$ polypropylene centrifuge tubes that were kept on ice. Within 300 minutes, the solution was centrifuged at $800 \mathrm{~g}$ for 5 minutes. The supernatant was recentrifuged at $1400 \mathrm{~g}$ for 5 minutes, and immediately frozen to $-20^{\circ} \mathrm{C}$.

Lysozyme was analyzed by means of radioimmunoassay (19). The concentrations of ECP and MPO were measured by means of a double antibody radioimmunoassay method (Pharmacia Diagnostics AB, Uppsala, Sweden) $(20,21)$. The intra- and interassay variation coefficients for all 3 tests were less than $11 \%$. Albumin was measured by rate nephelometry on an Array protein system (Beckman Instruments Inc).

\section{Statistical analysis}

Kendal's rank correlation coefficients were applied to investigate the correlation between 2 variables which can be expressed in a rank order. For comparisons of the distributions between 2 groups (wet mopping yes,no), the Mann-Whitney U-test was used. A multiple linear regression model was used for the control of potential confounders of age, gender, smoking habits, atopy, room temperature, and urban vicinity of the school (SPIDA statistical package, the Statistical Laboratory, Macquarie University, Australia) (22). In the multiple regression model, no major violations to the normal distribution of the residuals were present after the values for ECP, MPO, and albumin had been logarithmically transformed. Collinearity diagnostics were applied for the multiple linear regression model, adapted from that described by Belsey et al (23). As suggested, a conditioning index exceeding 30 was used as an indicator of collinearity problems 
in the linear regression model. Moderate collinearity problems were initially observed when room temperature was introduced into the model. These collinearity problems were eliminated by centering the room temperature, by subtracting the average value $\left(22.4^{\circ} \mathrm{C}\right)$ from all the room temperature values. Adjusted partial regression coefficients, with a $95 \%$ confidence interval, were calculated in the linear regression model. In all the statistical analyses, 2-tailed tests and a 5\% level of significance were applied.

\section{Ethics}

The protocol of the study was approved by the Ethical Committee of the Medical Faculty of the Uppsala University.

Table 3. Medians and interquartile ranges for the rhinometric measurements and lavage biomarkers. $(M C A 1=$ minimal cross-sectional area measured 0 to $22 \mathrm{~mm}$ from the nasal opening, MCA2 = minimal cross-sectional area measured 23 to $54 \mathrm{~mm}$ from the nasal opening, VOL1 = nasal cavity volume measured 0 to $22 \mathrm{~mm}$ from the nasal opening, VOL2 = nasal cavity volume measured 23 to $54 \mathrm{~mm}$ from the nasal opening, $\mathrm{ECP}=$ eosinophil cationic protein, MPO = myeloperoxidase)

\begin{tabular}{lcc}
\hline Nasal parameter & Median & Interquartile range \\
\hline MCA1 $\left(\mathrm{cm}^{2}\right)$ & 0.90 & $0.76-1.07$ \\
MCA2 $\left(\mathrm{cm}^{2}\right)$ & 1.06 & $0.85-1.32$ \\
VOL1 $\left(\mathrm{cm}^{3}\right)$ & 3.34 & $2.99-3.66$ \\
VOL2 $\left(\mathrm{cm}^{3}\right)$ & 7.25 & $6.08-8.60$ \\
ECP $(\mu \mathrm{g} / \mathrm{l})$ & 1.6 & $1.1-2.2$ \\
Lysozyme $(\mathrm{mg} / \mathrm{l})$ & 3.1 & $1.8-4.8$ \\
MPO $(\mu \mathrm{g} / \mathrm{l})$ & 21.5 & $10.0-44.9$ \\
Albumin $(\mathrm{mg} / \mathrm{l})$ & 5.6 & $3.0-10.9$ \\
\hline
\end{tabular}

Table 4. Kendall's tau correlation coefficients for the bivariate relations between the rhinometric data and lavage biomarkers on one hand and the total amount of settled dust (mg/sample) and absolute frequencies of floor mopping and desk cleaning (times/ week) in the classrooms on the other. (MCA1 = minimal cross-sectional area measured 0 to $22 \mathrm{~mm}$ from the nasal opening, MCA2 = minimal cross-sectional area measured 23 to $54 \mathrm{~mm}$ from the nasal opening, VOL1 = nasal cavity volume measured 0 to $22 \mathrm{~mm}$ from the nasal opening, VOL2 = nasal cavity volume measured 23 to $54 \mathrm{~mm}$ from the nasal opening, ECP = eosinophil cationic protein, MPO = myeloperoxidase)

\begin{tabular}{|c|c|c|c|c|c|c|}
\hline \multirow[t]{2}{*}{$\begin{array}{l}\text { Nasal } \\
\text { parameter }\end{array}$} & \multicolumn{2}{|c|}{$\begin{array}{l}\text { Total amount } \\
\text { of settled dust }\end{array}$} & \multicolumn{2}{|c|}{$\begin{array}{l}\text { Frequency of } \\
\text { floor mopping }\end{array}$} & \multicolumn{2}{|c|}{$\begin{array}{l}\text { Frequency of } \\
\text { desk cleaning }\end{array}$} \\
\hline & $\begin{array}{l}\text { Correlation } \\
\text { coefficient }\end{array}$ & $\begin{array}{lc}n & \mathrm{P}- \\
\text { it } & \text { value }\end{array}$ & $\begin{array}{l}\text { Correlation } \\
\text { coefficient }\end{array}$ & $\begin{array}{c}P- \\
\text { value }\end{array}$ & $\begin{array}{l}\text { Correlation } \\
\text { coefficient }\end{array}$ & t $\begin{array}{c}\mathrm{P}- \\
\text { t value }\end{array}$ \\
\hline $\operatorname{MCA1}\left(\mathrm{cm}^{2}\right)$ & -0.09 & 0.03 & 0.09 & 0.049 & 0.18 & $<0.001$ \\
\hline MCA2 $\left(\mathrm{cm}^{2}\right)$ & -0.19 & $<0.001$ & -0.001 & 0.49 & 0.10 & 0.02 \\
\hline VOL1 $\left(\mathrm{cm}^{3}\right)^{\prime}$ & 0.00 & 0.50 & 0.04 & 0.21 & 0.08 & 0.048 \\
\hline VOL2 $\left(\mathrm{cm}^{3}\right)$ & -0.09 & 0.03 & 0.02 & 0.38 & 0.05 & 0.15 \\
\hline $\operatorname{ECP}(\mu \mathrm{g} / /)$ & -0.01 & 0.39 & -0.09 & 0.04 & -0.07 & 0.08 \\
\hline Lysozyme (mg/l) & (l) 0.06 & 0.08 & -0.04 & 0.19 & -0.13 & 0.006 \\
\hline MPO $(\mu \mathrm{g} / \mathrm{l})$ & 0.05 & 0.17 & 0.08 & 0.06 & 0.08 & 0.07 \\
\hline Albumin (mg/) & 0.02 & 0.37 & -0.006 & 0.45 & 0.02 & 0.34 \\
\hline
\end{tabular}

\section{Results}

\section{Nasal symptoms, settled dust contaminants and cleaning routines}

Nasal symptoms were common; $50 \%$ of all the participants reported at least 1 nasal symptom the week prior to the medical investigation. The most frequent symptom was nasal obstruction (40\%). Nasal drop, nasal itching, and sneezing were less common $(19 \%, 10 \%$, and $24 \%$, respectively). A significant difference $(\mathrm{P}<0.05$, Mann-Whitney U-test) in the amount of dust in the classroom (arithmetic mean) was observed for the subjects reporting nasal obstruction (118 mg/sample) compared with those not reporting this symptom (103 $\mathrm{mg} / \mathrm{sample}$ ). The other nasal symptoms were not significantly related to the amount of dust collected. Furthermore, no significant relationship between any nasal symptom on one hand and the floor cleaning frequency, type of floor cleaning, or desk cleaning frequency on the other was observed.

\section{Objective nasal measurements and settled dust}

Descriptive data are given for the nasal dimensions and biomarkers in the nasal lavage in table 3 . The nasal cavity dimensions, MCA1, MCA2 and VOL2, were negatively related to the total amount of dust collected from the classrooms, whereas no lavage biomarker was related to the total amount of dust collected (table 4). Similar results were obtained in the multivariate model controlling for the effect of potential confounders (table 5).

\section{Objective nasal measurements and cleaning routines}

In a bivariate analysis, the anterior nasal cross-sectional areas, MCA1, were greater, and the lavage concentrations of ECP were lower among the subjects working in schools with a higher frequency of floor cleaning. MCA1, MCA2, and VOL1 were also greater and the concentrations of lysozyme lower in the schools with a higher frequency of desk cleaning (table 4). On the contrary, the use of wet mopping of the floors was associated with smaller nasal dimensions (MCA1 and MCA2) and higher concentrations of lysozyme in the lavage of the subjects (table 6). Similar relationships could be demonstrated after correction for potential confounders, using a multivariate model (table 5).

\section{Discussion}

Our results indicate that settled dust contamination in schools is related to nasal obstruction. The way cleaning is performed can also be related to nasal patency and signs of inflammatory activity in the nasal mucosa. 
Table 5. Multiple linear regression model with partial regression coefficients and $95 \%$ confidence intervals $(95 \% \mathrm{Cl}$ ) with corresponding P-values, showing the relations between 4 determinants (total amount of dust, frequency of floor mopping, frequency of desk cleaning, and use of any wet mopping in the school) and 6 potential confounders (age, gender, atopy, tobacco smoking, room temperature, and urban factor) as independent variables on one hand and rhinometric and lavage outcomes as dependent variables on the other. ${ }^{\text {a }}$ (MCA1 $=$ minimal cross-sectional area measured 0 to $22 \mathrm{~mm}$ from the nasal opening, MCA2 $=$ minimal cross-sectional area measured 23 to $54 \mathrm{~mm}$ from the nasal opening, VOL1 = nasal cavity volume measured 0 to $22 \mathrm{~mm}$ from the nasal opening, VOL2 = nasal cavity volume measured 23 to $54 \mathrm{~mm}$ from the nasal opening, ECP $=$ eosinophil cationic protein, MPO = myeloperoxidase)

\begin{tabular}{|c|c|c|c|c|c|c|c|c|c|c|c|c|}
\hline \multirow[t]{2}{*}{ Outcome variable } & \multicolumn{3}{|c|}{$\begin{array}{l}\text { Total amount of settled dust } \\
\text { (mg/sample) }\end{array}$} & \multicolumn{3}{|c|}{$\begin{array}{l}\text { Frequency of floor mopping } \\
\text { (times/week) }\end{array}$} & \multicolumn{3}{|c|}{$\begin{array}{l}\text { Frequency of desk cleaning } \\
\text { (times/week) }\end{array}$} & \multicolumn{3}{|c|}{$\begin{array}{l}\text { Wet mopping } \\
\text { (any wet mopping) }\end{array}$} \\
\hline & $\begin{array}{l}\text { Partial } \\
\text { regression } \\
\text { coefficient }\end{array}$ & nt & P-value & $\begin{array}{l}\text { Partial } \\
\text { regression } \\
\text { coefficient }\end{array}$ & $95 \% \mathrm{Cl}$ & P-value & $\begin{array}{l}\text { Partial } \\
\text { regression } \\
\text { coefficient }\end{array}$ & $95 \% \mathrm{Cl}$ & P-value & $\begin{array}{l}\text { Partial } \\
\text { regression } \\
\text { coefficient }\end{array}$ & $95 \% \mathrm{Cl}$ & P-value \\
\hline & & $-0.13--0.01$ & 0.009 & & & & & & & & & $<0.001$ \\
\hline & -0.20 & $-0.30-0.10$ & $<0.001$ & & & & & & 01 & & & 0.005 \\
\hline & -0.20 & & & 58 & & & & & 0.002 & & $2-143$ & 0.73 \\
\hline & & & & 88 & $-310-486$ & & & $-112-$ & & -731 & $0-146$ & 0.01 \\
\hline & $0.001-$ & -0.001 & 0. & $-0.15-$ & $-0.25-0.006$ & 60.002 & -0.15 & $-0.20-$ & $<0$. & 0.04 & -0.10 & 0.55 \\
\hline & & $-0.24-13$ & 0.0 & -212 & -795 & 0. & -6 & $-944-$ & $<0.00$ & 811 & $-54-$ & 0.07 \\
\hline $\log M$ & 0.001 & $-0.52-0.52$ & 0.26 & 0.07 & $-0.04-0.17$ & & 0.04 & $-0.01-0.10$ & & 0.06 & $-0.10-0.21$ & 0.45 \\
\hline albumin (mg/l) & 0.000 & $-0.002-0.002$ & 0.34 & -0.02 & $-0.11-0.07$ & 0.65 & -0.02 & $-0.07-0.03$ & 0.50 & 0.10 & $-0.03-0.23$ & 0.14 \\
\hline
\end{tabular}

a The unit of the regression coefficient was that of the outcome variable per 1 unit in change of the independent variable. The amount of dust, frequency of floor mopping and desk cleaning were continuous variables in the model, whereas the use of any wet mopping in the school was a dummy variable (dichotomous).

To our knowledge, this is the first epidemiologic investigation applying acoustic rhinometry and nasal lavage in relation to indoor particulate contamination and cleaning. Other studies in this field have used self-administered questionnaires (7) or in vitro tests on dust in cell cultures (9).

The design was cross-sectional and in such studies selection effects may result in an underestimation or an overestimation of the true relation. In this study, selection bias due to a low response rate was less likely since the participation rate was relatively high $(84 \%)$. Recall bias due to an awareness of exposure may affect symptom reporting, but it is unlikely to affect clinical signs of nasal congestion or biomarkers in nasal lavage fluid. Relatively many statistical tests were made, but there was mostly good agreement between the results from the crude analysis and the multiple regression analysis. Moreover, some parameters related to nasal obstruction were also related to increased levels of biomarkers in nasal fluid. Thus we do not believe that our conclusions are seriously biased by selection or response errors, or by chance findings. The cross-sectional design may, however, have caused an underestimation of the true effect if there was any health-based selection. Age, gender, smoking, atopy, room temperature, and urban vicinity were a priori considered as potential confounders and were controlled for without the results of the bivariate analysis being changed.

In our study increased amounts of settled dust in the classrooms were related to both self-reported nasal obstruction and reduced nasal patency measured via acoustic rhinometry. This finding is in agreement with the
Table 6. Nasal parameters for the personnel of the schools where wet mopping was used during the study period in comparison with schools without wet mopping. ${ }^{\text {a }}$ (MCA1 = minimal cross-sectional area measured 0 to $22 \mathrm{~mm}$ from the nasal opening, $\mathrm{MCA} 2=$ minimal cross - sectional area measured 23 to 54 $\mathrm{mm}$ from the nasal opening, $\mathrm{VOL} 1=$ nasal cavity volume measured 0 to $22 \mathrm{~mm}$ from the nasal opening, VOL2 = nasal cavity volume measured 23 to $54 \mathrm{~mm}$ from the nasal opening, ECP = eosinophil cationic protein, MPO = myeloperoxidase)

\begin{tabular}{|c|c|c|c|c|c|}
\hline \multirow[t]{2}{*}{ Nasal parameter } & \multicolumn{2}{|c|}{ Wet mopping } & \multicolumn{2}{|c|}{ No wet mopping } & \multirow[t]{2}{*}{ P-value ${ }^{b}$} \\
\hline & Median & $\begin{array}{l}\text { Interquartile } \\
\text { range }\end{array}$ & Median & $\begin{array}{l}\text { Interquartile } \\
\text { range }\end{array}$ & \\
\hline $\operatorname{MCA1}\left(\mathrm{cm}^{2}\right)$ & 0.86 & $0.74-1.0$ & 0.96 & $0.86-1.2$ & $<0.001$ \\
\hline $\operatorname{MCA2}\left(\mathrm{cm}^{2}\right)$ & 1.0 & $0.85-1.3$ & 1.2 & $0.91-1.5$ & 0.04 \\
\hline VOL1 $\left(\mathrm{cm}^{3}\right)$ & 3.3 & $3.0-3.6$ & 3.4 & $3.0-3.8$ & 0.44 \\
\hline VOL2 $\left(\mathrm{cm}^{3}\right)$ & 7.1 & $6.0-8.4$ & 7.7 & $6.2-9.1$ & 0.10 \\
\hline $\operatorname{ECP}(\mu \mathrm{g} / \mathrm{l})$ & 1.7 & $1.2-2.2$ & 1.4 & $1.0-2.3$ & 0.09 \\
\hline Lysozyme (mg/l) & 3.5 & $2.2-5.1$ & 2.8 & $1.4-4.2$ & 0.007 \\
\hline MPO $(\mu \mathrm{g} / \mathrm{l})$ & 21.0 & $10.0-45.2$ & 22.6 & $9.0-41.9$ & 0.708 \\
\hline Albumin $(\mathrm{mg} / \mathrm{l})$ & 5.8 & $3.0-11.0$ & 5.2 & $2.6-9.9$ & 0.31 \\
\hline
\end{tabular}

a The variable wet mopping was dichotomized into the use of wet mopping in the school at any time during the study period on one hand and no use at all of wet mopping on the other.

b Mann Whitney U-test.

results of previous studies showing more sick building symptoms in offices with more dust particles $(8,9)$.

Factors that can theoretically influence the removal of dust are both the frequency of cleaning and the type of cleaning methods, but very few health evaluations of different cleaning techniques could be found in the literature. In the present study smaller cross-sectional nasal areas and increased levels of ECP in lavage were 
correlated with a lower cleaning frequency in the schools. A previous study on floor mopping showed more symptoms of the sick building syndrome in Swedish offices with a low frequency of floor mopping (24), although the results were not statistically significant.

In our study we compared the effects of wet and dry floor mopping on the upper airways and found a negative effect of wet mopping when compared with dry mopping. One explanation for this difference could be that dry mopping is quicker and therefore makes it possible to clean a larger floor area in a specified time period. One study showed that dry mopping was 9 times faster than wet cleaning, but it had the same effect on dust removal (25). Another possibility is that wetting of the floors could sustain the growth of microorganisms and also be detrimental to some floor materials, such as linoleum (26), which was used in $50 \%$ of the classrooms in our study.

The beneficial effects of cleaning routines other than floor mopping was pointed out by Raw et al (7), who showed that the cleaning of furniture reduced sick building symptoms. This conclusion is in agreement with the findings of our study, which showed that the use of desk cleaning was related to both greater nasal cavity dimensions and lower concentrations of lavage biomarkers among the school personnel.

The mechanisms behind the observed relationships mainly focus on the effect of dust. We used the amount of settled dust collected from floors and furniture as an assessment of exposure. In a crowded environment, such as a classroom, physical activities are important for the redispersion of surface dust; they cause great variations of air dust levels during the day. A correlation between the number of people in a room and airborne dust, and also a correlation between surface dust and air levels, has been shown (27). Thorough cleaning of floors and other surfaces in an office building can reduce the airborne dust level by $50 \%$ (28). Larger particles may be deposited on the nasal mucosa, and, as a consequence, mucosal swelling and inflammation may occur. In a previous study using adrenergic nasal spray (12), we showed that dust exposure was related to an increased decongestive effect; this finding indicates a reversible vascular response of the mucosa. In the present study there was also some agreement between nasal dimensions and the concentrations of 2 inflammatory markers (ie, ECP and lysozyme). This finding indicates that these lavage biomarkers may have clinical significance in relation to indoor air pollution. ECP is used as a marker of the activity of eosinophil granulocytes, and lysozyme is a marker of the glandular activity of the mucosa.

In conclusion, our results indicate that dust accumulation in the classroom is related to nasal obstruction among school personnel. When specific cleaning methods were examined, a positive effect on clinical signs from the nasal mucosa was observed for desk cleaning and dry mopping. This finding illustrates the need for both sufficient and adequate cleaning routines to reduce dust exposure. Especially desk cleaning is a cost efficient cleaning method, which can be done by the pupils themselves. Finally acoustic rhinometry, in combination with the determination of specific biomarkers of inflammation in nasal lavage fluid, can be useful methods for detecting human nasal reactions related to particulate pollutants, and these objective methods seem to be more sensitive than symptom reporting only.

\section{Acknowledgments}

This study was supported by grants from the Swedish Council for Worklife Research, Swedish Association against Asthma and Allergy, The Swedish Medical Research Council, The Swedish Society of Medicine, and the County Council of Uppsala.

\section{References}

1. Heyman E. Bidrag till kännedomen om luftens beskaffenhet i skolor [Contribution to the knowledge on the quality of air in schools]. Nord Med Ark 1880; XII(2):1—47. French summary.

2. Munir AKM, Einarsson R, Shou C, Dreborg SKG. Allergens in school dust. J Allergy Clin Immunol 1993;91:1067-74.

3. Smedje G, Norbäck D, Edling C. Asthma among secondary schoolchildren in relation to the school environment. Clin Exp Allergy 1997;27:1270—8.

4. Einarsson G, Munir A, Dreborg S. Allergens in school dust II. Major mite (Der p 1, Der $\mathrm{f}$ 1) allergens in dust from Swedish schools. J Allergy Clin Immunol 1995;95:1049-53.

5. Wickman M, Gravesen S, Nordvall SL, Pershagen G, Sundell $\mathrm{J}$. Indoor viable dust-bound microfungi in relation to residential characteristics, living habits, and symptoms in atopic and control children. J Allergy Clin Immunol 1992;89:752-9.

6. Roberts J, Budd W, Ruby M, Camann D, Fortman R, Lewis $R$, et al. Human exposure to pollutants in the floor dust of homes and offices. J Exposure Anal Environ Epidemiol 1992;suppl 1:127-46.

7. Raw G, Roys M, Whitehead C. Sick building syndrome: cleanliness is next to healthiness. Indoor Air 1993;3:237-45.

8. Skov P, Valbjørn O, Pedersen BV, the Danish Indoor Climate Study Group. Influence of indoor climate on the sick building syndrome in an office environment. Scand J Work Environ Health $1990 ; 16: 363-71$.

9. Gyntelberg F, Saudicani P, Wohlfart-Nielsen J, Skov P, Valbjorn $O$, Nielsen PA, et al. Dust and the sick building syndrome. Indoor Air 1994;4:223-38.

10. Smedje G, Norbäck D, Edling C. Subjective indoor air quality in schools in relation to exposure. Indoor Air 1997;7:14359.

11. Pedersen $\mathrm{OF}$, Hilberg $\mathrm{O}$. Acoustic rhinometry-what is measured? Aarhus (Denmark): The ERS Committee for Standardi- 
zation of Acoustic Rhinometry, The Institute of Environmental and Occupational Medicine, University of Aarhus, 1994.

12. Wålinder R, Norbäck D, Wieslander G, Smedje G, Erwall C. Nasal mucosal swelling in relation to low air exchange rate in schools. Indoor Air 1997;7:198-205.

13. Åhman M, Holmström M, Ingelman-Sundberg H. Inflammatory markers in nasal lavage fluid from industrial arts teachers. Am J Ind Med 1995;28:540-50.

14. Peden DB. The use of nasal lavage for objective measurement of irritant-induced nasal inflammation. Regul Toxicol Pharmacol 1996;24:76-8.

15. Pipkorn N, Karlsson G, Enerbäck L. Nasal mucosal response to repeated challenges with pollen allergen. Am Rev Respir Dis 1989;140:729-36.

16. Raphael GD, Jeney EV, Baraniuk JN, Kim I, Meredith SD, Kaliner MA. Pathophysiology of rhinitis, lactoferrin and lysozyme in nasal secretions. J Clin Invest 1989;84:1528-35.

17. Bischoff E, Kniest F, Shirmacher W. Results in dust samples with a new quantitative guanine assessment and evaluating of risk groups. Environ Technol 1992;13:377-82.

18. Friberger P, Knös M, Mellstam L. A quantitative endotoxin assay utilizing LAL and a chromogenic substrate. In: Stanley WW, Levin J, editors. Endotoxins and their detection with the limulus amebocyte lysate. New York (NY): Alan R Liss Inc, 1982:195-206. Prog Clin Biol Res, vol 93.

19. Venge P, Hällgren R, Stălenheim G, Olsson I. Effects of serum and cations on the selective release of granular proteins from human neutrophils during phagocytosis. Scand J Haematol 1979;22:317-26.

20. Schmekel B, Karlsson SE, Linden K, Sundström C, Tegner H, Venge P. Myeloperoxidase in human lung lavage, I: a marker of local neutrophil activity. Inflammation 1990;14:447-54.

21. Peterson CGB, Nystrand J, Andersson AS, Nilsson L, Venge
P. Radioimmunoassay of human eosinophil cationic protein by an improved method: establishment of normal levels in serum turnover in vivo. Clin Exp Allergy 1991;21:561-7.

22. Grebski V, Leung O, McNeil D, Lunn D. SPIDA users manual, version 6. Eastwood (Australia): Statistical Computing Laboratory, 1992.

23. Belsley D, Kuh E, Welsh R. Regression diagnostics. New York (NY): John Wiley and Sons, 1980.

24. Stenberg B, Eriksson N, Mild KH, Höög J, Sandström M, Sundell J, et al. Facial skin symptoms in visual display terminal (VDT) workers: a case-referent study of personal, psychosocial, building-and VDT-related risk indicators. Int J Epidemiol 1995;24:796-803.

25. Hellström B, Greger I, Jansson T, Jahr J. Gulvrengjöring. Arbeidsbelastning og rengöringseffekt ved bruk av våtvask og torrmopp [Floor cleaning: work load and cleaning effect of wet cleaning or dry mopping]. Oslo: Yrkeshygienisk Institutt, Arbeidsforskningsinstituttene, 1969.

26. Follin T. Powdering and other linoleum carpet problems. In: Flatheim G, Berg KR, Edvardsen KI, editors. International symposium, indoor air quality in practice, Oslo, Norway, June 1995. Oslo: Norwegian Society of Chartered Engineers, 1995:377-80.

27. Kildesö J, Tornvig L, Skov P, Schneider T. An intervention study of the effect of improved cleaning methods on the concentration and composition of dust. Indoor Air 1998:8:12-22.

28. Franke DL, Cole EC, Leese KE, Foarde KK, Berry MA. Cleaning for improved indoor air quality: an initial assessment of effectiveness. Indoor Air 1997;7:41—54.

Received for publication: 22 June 1998 